\title{
Health status of cereals in dependence on the organic fertilization
}

\section{Zdrowotność zbóż w zależności od nawożenia organicznego}

\author{
Tomasz P. Kurowski ${ }^{1}$, Wiera Sądej ${ }^{2}$, Karolina Kacprzak-Siuda ${ }^{1}$, \\ Edyta Kwiatkowska ${ }^{1}$, Elżbieta Kowalska ${ }^{1}$
}

\section{Summary}

The study was carried out on experimental plots in Tomaszkowo (53.7 N, 20.4 E) near Olsztyn in 2007-2008. A long-term, strict experiment was set up in 1972 according to the random plot design with six replications. Pig liquid manure and farmyard manure were used in the experiment. Phosphorus and potassium applied in the amount of $1 / 2$ dose half of the plots of pig liquid manure and farmyard manure. The control object was not fertilized. The study included spring barley and winter. The highest occurrence of disease was on the treatment fertilized with higher dose of liquid manure, while the lowest in the control object. Fungi of the genus Fusarium constituted the most threat to cultivated cereals. F. oxysporum, F. culmorum and F. equiseti were most frequently isolated from the stem base.

Key words: diseases; fungi; spring barley; winter wheat; pig liquid manure; farmyard manure; mineral fertilization

\section{Streszczenie}

Badania prowadzono w latach 2007-2008 na poletkach doświadczalnych w Tomaszkowie (53,7 N, 20,4 E) koło Olsztyna, na glebie piaszczystej należącej do kompleksu żytniego dobrego. Ścisłe doświadczenie statyczne założono w 1972 roku metodą losowanych bloków w sześciu powtórzeniach. W doświadczeniu stosowano gnojowicę świńską i obornik. Na połowie poletek nawożonych gnojowicą i obornikiem zastosowano mineralne nawożenie fosforowo-potasowe w wysokości $1 / 2$ dawki tych składników wprowadzanych na obiekcie z wyłącznym nawożeniem mineralnym. Obiekt kontrolny nie był nawożony. Badaniami objęto jęczmień jary oraz pszenicę ozimą. Najwyższe nasilenie chorób odnotowano na obiekcie nawożonym większą dawką gnojowicy, natomiast najniższe na obiekcie kontrolnym. Grzyby rodzaju Fusarium stanowiły największe zagrożenie dla uprawianych zbóż. Z porażonych źdźbeł zbóż najczęściej izolowano: F. oxysporum, F. equiseti i F. culmorum.

Słowa kluczowe: choroby; grzyby; jęczmień jary; pszenica ozima; nawożenie gnojowicą; nawożenie obornikiem; nawożenie mineralne

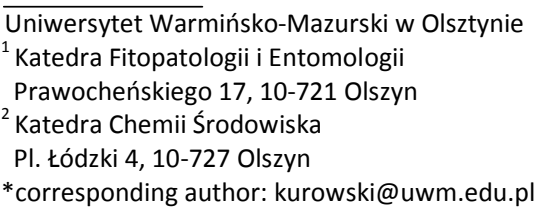




\section{Wstęp / Introduction}

Środowisko glebowe mogą znacząco zmieniać zarówno nawożenie mineralne, jak i organiczne. W dzisiejszym świecie nawożenie jako czynnik modyfikujący właściwości gleby, musi być podstawowym zabiegiem utrzymującym żyzność gleby na poziomie pozwalającym produkować wystarczającą ilość żywności (Cwojdziński i Nowak 2000). Potencjał plonotwórczy związany jest $z$ jej właściwościami fizykochemicznymi i biologicznymi (Gutmański i Mikita 2000). Kierunki przemian, które zachodzą w glebie zależą w dużym stopniu od: aktywności mikroorganizmów, dostępu tlenu, temperatury, wilgotności i odczynu, a także od zabiegów agrotechnicznych i wysokości dawek nawozów (Hamkalo 2000). Nieodpowiednie nawożenie może doprowadzić do degradacji gleby oraz obniżyć jej produktywność w wyniku zakwaszenia i zachwiania równowagi jonowej w środowisku glebowym. Wielu autorów podkreśla niekorzystny wpływ niezrównoważonego nawożenia mineralnego na niektóre elementy żyzności gleby (Fotyma i Pietruch 2005). W praktyce rolniczej odnosi się to głównie do nawozów mineralnych, gdyż nawozów organicznych nie stosuje się za często i w zbyt dużych dawkach (Mercik i wsp. 2000). Wyłączne stosowanie nawozów organicznych nie zapewnia odpowiedniej równowagi składników pokarmowych. Według Kaczora i Kozłowskiej (2003) najbardziej korzystne efekty osiąga się stosując obornik łącznie $\mathrm{z}$ nawozami mineralnymi.

Nawożenie roślin uprawnych wpływa na liczebność oraz skład gatunkowy mikroorganizmów zasiedlających glebę i może przyczynić się do wzrostu liczebności patogenów roślin lub ich antagonistów, a tym samym wpływać na ich zdrowotność (Żółtańska i Woźniak 2003).

Celem badań było porównanie wpływu zróżnicowanego nawożenia gnojowica lub obornikiem na stan zdrowotny dwóch gatunków zbóż i skład gatunkowy grzybów zasiedlających porażone korzenie i podstawy źdźbła.

\section{Materiały i metody / Materials and methods}

Badania prowadzono w latach 2007-2008 na poletkach doświadczalnych Zakładu Dydaktyczno-Doświadczalnego w Tomaszkowie $(53,7 \mathrm{~N}, 20,4 \mathrm{E})$, na glebie piaszczystej należącej do kompleksu żytniego dobrego. Ścisłe doświadczenie statyczne zostało założone przez Katedrę Chemii Środowiska Uniwersytetu Warmińsko-Mazurskiego w Olsztynie w 1972 roku metodą losowanych bloków w sześciu powtórzeniach. W doświadczeniu zastosowano gnojowicę świńską (stosowaną w dwóch dawkach) i obornik. Na połowie poletek nawożonych gnojowicą i obornikiem zastosowano mineralne nawożenie fosforowo-potasowe w ilości $1 / 2$ dawki tych składników wprowadzanych $\mathrm{w}$ obiekcie jedynie $\mathrm{z}$ nawożeniem mineralnym. Obiekt kontrolny stanowiły poletka nienawożone. Nawozy organiczne i mineralne stosowano na dwa do trzech dni przed siewem roślin. Zabiegi agrotechniczne wykonywano w optymalnych dla roślin terminach, zgodnie z zasadami prawidłowej agrotechniki.

\section{Obiekty doświadczenia}

Bez nawożenia (kontrola).

Gnojowica (37,2 t/ha).

Gnojowica $(37,2 \mathrm{t} / \mathrm{ha})+$ PK $(39,5+59,3 \mathrm{~kg} / \mathrm{ha})$.

Gnojowica (66,4 t/ha).

Gnojowica (66,4 t/ha) + PK $(39,5+59,3 \mathrm{~kg} / \mathrm{ha})$.

Obornik (20,6 t/ha).

Obornik (20,6 t/ha) + PK (39,5+59,3 kg/ha).

NPK $(100,2+79,0+119,0 \mathrm{~kg} / \mathrm{ha})$.

Gnojowicę zastosowano w dwóch dawkach: niższej równej obornikowi pod względem ilości wnoszonego do gleby azotu ogółem oraz w dawce wyższej - odpowiadającej obornikowi pod względem ilości wnoszonego do gleby węgla organicznego.

Rośliny uprawiano w płodozmianie: ziemniak, jęczmień jary, rzepak ozimy, pszenica ozima + żyto ozime, kukurydza, jęczmień jary, pszenica ozima. W latach 2007, 2008 na poletkach doświadczalnych rosły kolejno jęczmień jary i pszenica ozima.

Analizę zdrowotności korzeni pszenicy ozimej wykonano w fazie $\mathrm{BBCH} 39$, liści oraz kłosów w fazie $\mathrm{BBCH} 75$, a podstawy źdźbła w fazie BBCH 85. Do oceny zdrowotności korzeni pszenicy ozimej zastosowano metodę Łacicowej (1964), aparatu asymilacyjnego zastosowano metodę Hinfnera i Pappa (1964), natomiast podstawy źdźbła - metodę Mackiewicza i Drath (1972). Uzyskane dane przedstawiono w postaci indeksu porażenia. Wyniki opracowano statystycznie przy użyciu analizy wariancji (STATISTICA v. 10). Z korzeni pszenicy ozimej z objawami chorób podsuszkowych izolowano grzyby zgodnie z metodą Martyniuka (1986), natomiast z podstawy źdźbła obydwu zbóż zgodnie z metodą Reineckego i Fehrmanna (1979).

Okres wegetacyjny w roku uprawy jęczmienia jarego (2007) rozpoczął się pod koniec marca. Był to rok ciepły o średniej temperaturze powyżej średniej z lat 1961-2000. Opady atmosferyczne utrzymywały się również powyżej średniej wieloletniej. Bardzo mokre okazały się: maj, czerwiec i lipiec. Wrzesień i październik 2007 roku były ciepłe. Pszenica ozima miała optymalne warunki do kiełkowania i początkowego rozwoju. Okres spoczynku trwał od początku listopada do końca marca. Wegetacja pszenicy ozimej ruszyła w kwietniu. Temperatura w czerwcu, lipcu i sierpniu utrzymywała się powyżej średniej wieloletniej, w pozostałych miesiącach była zbliżona do średniej z lat 1961-2000. Opady atmosferyczne były niewielkie, zdecydowanie poniżej średniej z lat 1961-2000.

\section{Wyniki i dyskusja / Results and discussion}

$\mathrm{Na}$ jęczmieniu jarym wystąpiły: mączniak prawdziwy zbóż i traw (Blumeria graminis), rynchosporioza zbóż (Rhynchosporium secalis), plamistość siatkowa (Helminthosporium teres), rdza jęczmienia (Puccinia hordei), fuzarioza kłosów (Fusarium spp.), fuzaryjna zgorzel podstawy źdźbła (Fusarium spp.) oraz łamliwość źdźbła zbóż (Tapesia yallundae) (tab. 2). Mączniak prawdziwy zbóż i traw, rynchosporioza zbóż i plamistość siatkowa liczniej występowały na wszystkich obiektach nawożonych gnojowicą, natomiast najsłabiej opanowały jęczmień na 
obiekcie nawożonym obornikiem z PK i na obiekcie nienawożonym. Najwyższe nasilenie fuzariozy kłosów stwierdzono na roślinach $\mathrm{w}$ obrębie obiektu nawożonego gnojowicą w większej dawce oraz większej z PK, a najniższe na obiekcie kontrolnym i obiekcie nawożonym obornikiem z PK. Rdza jęczmienia w najwyższym nasileniu opanowała rośliny $\mathrm{w}$ obiekcie $\mathrm{z}$ większą dawką gnojowicy. W obiekcie kontrolnym i nawożonym obornikiem z PK objawów rdzy nie stwierdzono. W śladowej ilości wystąpiła w obiekcie nawożonym nawozami mineralnymi. Spośród chorób podstawy źdźbła w zdecydowanie większym nasileniu wystąpiła fuzaryjna zgorzel podstawy źdźbła. Wyższe nasilenie stwierdzono na roślinach w obrębie obiektu nawożonego nawozami mineralnymi oraz mniejszą dawką gnojowicy, natomiast najniższe nasilenie w obiekcie nawożonym obornikiem z PK. W obiekcie kontrolnym i nawożonym niższą dawką gnojowicy stwierdzono najwyższe nasilenie łamliwości źdźbła zbóż, natomiast najniższe na obiekcie nawożonym wyższą dawką gnojowicy z PK oraz obornikiem (tab. 2).

Na pszenicy ozimej wystąpiły: zgorzel korzeni (Fusarium spp.), fuzaryjna zgorzel podstawy źdźbła (Fusarium spp.), łamliwość źdźbła zbóż ( $T$. yallundae), a także ostra plamistość oczkowa (R. cerealis) (tab. 3). Zgorzel korzeni najliczniej rozwijała się w obiekcie kontrolnym, natomiast najmniej licznie w obiekcie nawożonym gnojowicą w większej dawce z PK. Na roślinach w obrębie obiektu nawożonego gnojowicą $\mathrm{W}$ mniejszej i większej dawce z PK stwierdzono wyższe nasilenie fuzaryjnej zgorzeli podstawy źdźbła niż w obiekcie nawożonym obornikiem. Najwyższe nasilenie występowania objawów łamliwości źdźbła zbóż i traw stwierdzono w obiekcie nawożonym nawozami mineralnymi, a najniższe w obiekcie kontrolnym i nawożonym obornikiem z PK. Ostra plamistość oczkowa w najwyższym nasileniu występowała w obiekcie nawożonym obornikiem $\mathrm{z}$ PK, natomiast w najniższym w obiekcie kontrolnym (tab. 3). W ciągu sezonu wegetacyjnego nie zaobserwowano objawów chorób liści i kłosów.

Okres wegetacyjny jęczmienia jarego w 2007 roku sprzyjał występowaniu chorób liści i kłosów jęczmienia (Kurowski i wsp. 2005). Ze względu na krótki okres wegetacji jęczmienia jarego, choroby podsuszkowe nie stanowią zagrożenia dla jego uprawy (Korbas i wsp. 2001). Wydaje się, że na niskie nasilenie łamliwości źdźbła zbóż miała wpływ wysoka temperatura w okresie wegetacji (Kurowski i wsp. 2005).

$\mathrm{Na}$ pszenicy ozimej nie stwierdzono występowania chorób aparatu asymilacyjnego. Wpływ na to miał przebieg warunków pogodowych wiosną i latem 2008 roku, a szczególnie bardzo niskie opady w tym okresie (Kurowski 2002; Majchrzak i wsp. 2004). Również o niskim nasileniu łamliwości źdźbła zbóż zdecydował przebieg pogody. Zakończenie wegetacji na początku listopada i ruszenie jej w kwietniu, przy jednoczesnym niedoborze wilgoci nie sprzyjało rozwojowi T. yallundae (Jaczewska-Kalicka i Krasiński 2010).

Wielu autorów podaje, że wzrastające dawki nawozów azotowych mogą w odpowiednich warunkach pogodowych zmniejszać odporność zbóż na patogeny, jak również wpływać na wzmożone formowanie zarodników i chlamydospor (Brzozowski i wsp. 2000; Jaczewska-Kalicka 2006). W przeprowadzonych badaniach zaobserwowano, że nawożenie obornikiem $\mathrm{z}$ dodatkiem nawozów fosforowo-potasowych pozytywnie wpłynęło na zdrowotność jęczmienia jarego w porównaniu do nawożenia gnojowicą. Nawożenie obornikiem poprawia strukturę gleby i sprzyja rozwojowi organizmów antagonistycznych w stosunku do grzybów patogenicznych dla zbóż (Filipek 2005).

$\mathrm{Z}$ porażonych źdźbeł jęczmienia jarego wyizolowano 140 izolatów grzybów, w tym 38 izolaty stanowiły potencjalne patogeny, a 79 kolonii to grzyby wykazujące działanie antagonistyczne wobec patogenów, które najliczniej izolowano $\mathrm{z}$ obiektu kontrolnego, nawożonego gnojowicą w mniejszej dawce $\mathrm{z}$ PK, a także obornikiem z PK i obiektu nawożonego jedynie nawozami mineralnymi (tab. 4). Potencjalne patogeny najliczniej występowały na obiekcie kontrolnym oraz na obiekcie nawożonym obornikiem i obornikiem z PK, a także nawożonym jedynie nawozami mineralnymi. $Z$ grupy grzybów wykazujących działanie antagonistyczne wobec patogenów zbóż najliczniej izolowano grzyby rodzaju Penicillium (53 kolonie). Spośród potencjalnych patogenów najliczniejszą grupą były grzyby rodzaju Fusarium (35 kolonii). Liczniej występowały one na obiektach nawożonych jedynie nawozami mineralnymi, obornikiem oraz na obiekcie kontrolnym, natomiast najmniej licznie występowały na obiektach nawożonych gnojowicą w niższej dawce oraz gnojowicą z PK (tab. 4).

Zarówno z korzeni, jak i z podstawy źdźbła pszenicy ozimej wyizolowano po 141 izolatów grzybów. Z korzeni pszenicy ozimej wyizolowano 35 izolatów grzybów wykazujących działanie patogeniczne, a 66 to izolaty wykazujące działanie antagonistyczne wobec patogenów (tab. 5). Grzyby rodzaju Fusarium stanowiły 20 izolatów i najczęściej izolowano je z kombinacji nawożonych jedynie nawozami mineralnymi, natomiast najrzadziej $\mathrm{z}$ kombinacji nawożonych gnojowicą $\mathrm{w}$ mniejszej dawce $\mathrm{z}$ PK (tab. 5).

Z podstawy źdźbła pszenicy ozimej uzyskano 73 izolaty grzybów będących potencjalnymi patogenami zbóż oraz 20 izolatów grzybów uważanych za antagonistyczne wobec patogenów (tab. 6). Ogółem uzyskano 65 izolatów grzybów rodzaju Fusarium występujących w najwyższym nasileniu na obiekcie nawożonym obornikiem, a w najniższym nasileniu na obiekcie nawożonym mniejszą dawką gnojowicy z PK (tab. 6).

Grzyby rodzaju Fusarium stanowiły największe zagrożenie dla uprawianych zbóż. $Z$ porażonych korzeni pszenicy ozimej najczęściej izolowano $F$. equiseti, $F$. tricinctum i $F$. poae. $Z$ porażonych źdźbeł jęczmienia jarego i pszenicy ozimej najczęściej izolowano $F$. oxysporum, $F$. equiseti i $F$. culmorum. Zarówno u jęczmienia jarego, jak i u pszenicy ozimej grzyby rodzaju Fusarium najliczniej występowały na obiekcie nawożonym obornikiem i jedynie nawozami mineralnym, natomiast najmniej licznie na obiekcie nawożonym gnojowicą w mniejszej dawce oraz w kontroli. Podobne wyniki uzyskali Majchrzak i wsp. (2004), którzy odnotowali silniejsze porażenie podstawy źdźbła przy zwiększonym nawożeniu azotowym w porównaniu do obiektów bez takiego nawożenia.

Najbardziej niebezpiecznymi gatunkami patogenicznymi, które występowały w doświadczeniu były grzyby rodzaju Fusarium. Występują one zarówno na korzeniach, 
Tabela 1. Warunki pogodowe w Tomaszkowie w latach 2007 i 2008

Table 1. Meteorological conditions in Tomaszkowo 2007 and 2008 years

\begin{tabular}{|c|c|c|c|c|c|c|c|c|c|c|c|c|c|}
\hline $\begin{array}{l}\text { Wyszczególnienie } \\
\text { Specification }\end{array}$ & \multirow{2}{*}{$\begin{array}{l}\text { Rok } \\
\text { Year }\end{array}$} & \multicolumn{12}{|c|}{ Miesiące - Months } \\
\hline \multirow{4}{*}{$\begin{array}{l}\text { Średnia } \\
\text { temperatura } \\
\text { powietrza } \\
\text { Mean air } \\
\text { temperature }\left[{ }^{\circ} \mathrm{C}\right]\end{array}$} & & I & II & III & IV & $\mathrm{V}$ & VI & VII & VIII & IX & $\mathrm{X}$ & $\mathrm{XI}$ & XII \\
\hline & 2007 & 2,7 & $-2,7$ & 5,6 & 7,5 & 13,6 & 17,7 & 17,7 & 18,3 & 12,6 & 7,5 & 1,3 & 0,6 \\
\hline & 2008 & 0,3 & 2,6 & 2,9 & 7,7 & 12,3 & 16,9 & 18,4 & 18,4 & 15,1 & 8,7 & 4,1 & 0,2 \\
\hline & $\begin{array}{l}\text { wielolecie* } \\
\text { many years }\end{array}$ & $-3,0$ & $-2,6$ & 1,2 & 6,7 & 12,7 & 15,9 & 17,8 & 17,2 & 12,6 & 7,8 & 2,6 & $-1,2$ \\
\hline \multirow{3}{*}{$\begin{array}{l}\text { Opady } \\
\text { atmosferyczne } \\
\text { Precipitation }[\mathrm{mm}]\end{array}$} & 2007 & 115,4 & 23,5 & 27,8 & 24,7 & 93,5 & 88,1 & 173,7 & 68,0 & 57,9 & 30,2 & 33,8 & 27,8 \\
\hline & 2008 & 66,2 & 24,7 & 52,4 & 31,4 & 27,0 & 32,7 & 57,7 & 102,1 & 22,9 & 82,8 & 29,4 & 35,1 \\
\hline & $\begin{array}{l}\text { wielolecie** } \\
\text { many years }\end{array}$ & 29,0 & 19,7 & 26,4 & 35,2 & 49,1 & 81,9 & 71,2 & 67,0 & 63,5 & 45,4 & 49,8 & 38,2 \\
\hline
\end{tabular}

*średnia wielolecia 1961-2000 - long-term mean 1961-2000

**suma wielolecia 1961-2000 - long-term sum 1961-2000

Tabela 2. Nasilenie chorób jęczmienia jarego w zależności od nawożenia (indeks porażenia w \%) (Tomaszkowo, 2007)

Table 2. Intensity of spring barley diseases in the dependence on fertilization (injury index in \%) (Tomaszkowo, 2007)

\begin{tabular}{|c|c|c|c|c|c|c|c|c|c|}
\hline \multirow{2}{*}{$\begin{array}{l}\text { Choroba - Patogen } \\
\text { Disease - Pathogen }\end{array}$} & \multicolumn{8}{|c|}{ Obiekty - Objects } & \multirow{2}{*}{$\begin{array}{l}\operatorname{NIR}(0,05) \\
\operatorname{LSD}(0.05)\end{array}$} \\
\hline & I & II & III & IV & $\mathrm{V}$ & VI & VII & VIII & \\
\hline $\begin{array}{l}\text { Mączniak prawdziwy zbóż i traw } \\
\text { Blumeria graminis }\end{array}$ & 12,0 & 21,7 & 30,3 & 37,3 & 33,0 & 18,0 & 9,0 & 15,0 & 3,35 \\
\hline $\begin{array}{l}\text { Rynchosporioza zbóż } \\
\text { Rhynchosporium secalis }\end{array}$ & 1,0 & 9,0 & 19,7 & 13,7 & 13,0 & 6,7 & 0,7 & 3,7 & 1,70 \\
\hline $\begin{array}{l}\text { Plamistość siatkowa } \\
\text { Helminthosporium teres }\end{array}$ & 7,0 & 12,7 & 9,3 & 14,7 & 14,7 & 11,3 & 6,0 & 8,7 & 2,45 \\
\hline Rdza jęczmienia - Puccinia hordei & 0,0 & 4,7 & 3,3 & 11,7 & 6,3 & 8,3 & 0,0 & 0,3 & 1,62 \\
\hline Fuzarioza kłosów - Fusarium spp. & 0,0 & 2,7 & 4,3 & 6,0 & 3,3 & 2,0 & 0,3 & 3,0 & 1,27 \\
\hline $\begin{array}{l}\text { Fuzaryjna zgorzel podstawy źdźbła } \\
\text { Fusarium spp. }\end{array}$ & 16,0 & 26,7 & 16,0 & 20,0 & 20,0 & 18,7 & 11,3 & 27,3 & 2,24 \\
\hline $\begin{array}{l}\text { Łamliwość źdźbła zbóż - Tapesia } \\
\text { yallundae }\end{array}$ & 2,7 & 2,7 & 1,3 & 2,0 & 0,0 & 0,0 & 0,7 & 0,7 & 1,58 \\
\hline \multicolumn{10}{|c|}{$\begin{array}{l}\text { I - bez nawożenia (kontrola) - without fertilization (control) } \\
\text { II - gnojowica }(37,2 \mathrm{t} / \mathrm{ha})-\text { pig liquid manure }(37.2 \mathrm{t} / \mathrm{ha}) \\
\text { III - gnojowica }(37,2 \mathrm{t} / \mathrm{ha})+\mathrm{PK}(39,5+59,3 \mathrm{~kg} / \mathrm{ha})-\text { pig liquid manure }+ \text { phosphorus and potassium }(39.5+59.3 \mathrm{~kg} / \mathrm{ha}) \\
\text { IV - gnojowica }(66,4 \mathrm{t} / \mathrm{ha})-\text { pig liquid manure }(66.4 \mathrm{t} / \mathrm{ha}) \\
\mathrm{V}-\text { gnojowica }(66,4 \mathrm{t} / \mathrm{ha})+\mathrm{PK}(39,5+59,3 \mathrm{~kg} / \mathrm{ha})-\text { pig liquid manure }(66.4 \mathrm{t} / \mathrm{ha})+\text { phosphorus and potassium }(39.5+59.3 \mathrm{~kg} / \mathrm{ha}) \\
\text { VI - obornik }(20,6 \mathrm{t} / \mathrm{ha})-\text { farmyard manure }(20.6 \mathrm{t} / \mathrm{ha}) \\
\text { VII - obornik }(20,6 \mathrm{t} / \mathrm{ha})+\mathrm{PK}(39,5+59,3 \mathrm{~kg} / \mathrm{ha})-\text { farmyard manure }(20.6 \mathrm{t} / \mathrm{ha})+\text { phosphorus and potassium }(39.5+59.3 \mathrm{~kg} / \mathrm{ha}) \\
\text { VIII - NPK }(100,2+79,0+119,0 \mathrm{~kg} / \mathrm{ha})-\text { nitrogen, phosphorus, potassium }(100.2+79.0+119.0 \mathrm{~kg} / \mathrm{ha})\end{array}$} \\
\hline \multirow{2}{*}{$\begin{array}{l}\text { Choroba - Patogen } \\
\text { Disease - Pathogen }\end{array}$} & \multicolumn{8}{|c|}{ Obiekty - Objects } & \multirow{2}{*}{$\begin{array}{l}\operatorname{NIR}(0,05) \\
\operatorname{LSD}(0.05)\end{array}$} \\
\hline & I & II & III & IV & $\mathrm{V}$ & VI & VII & VIII & \\
\hline Zgorzel korzeni - Fusarium spp. & 17,2 & 11,5 & 10,5 & 10,2 & 5,5 & 10,2 & 9,0 & 10,7 & 4,23 \\
\hline $\begin{array}{l}\text { Fuzaryjna zgorzel podstawy źdźbła } \\
\text { Fusarium spp. }\end{array}$ & 11,5 & 11,5 & 21,5 & 10,0 & 19,5 & 4,5 & 17,0 & 10,5 & 8,50 \\
\hline $\begin{array}{l}\text { Łamliwość źdźbła zbóż - Tapesia } \\
\text { yallundae }\end{array}$ & 0,5 & 0,5 & 1,0 & 3,0 & 1,5 & 4,0 & 0,5 & 4,5 & 3,89 \\
\hline $\begin{array}{l}\text { Ostra plamistość oczkowa } \\
\text { Rhizoctonia cerealis }\end{array}$ & 0,2 & 4,5 & 7,2 & 6,0 & 4,5 & 2,5 & 11,5 & 2,0 & 3,70 \\
\hline
\end{tabular}

Objaśnienia pod tabelą 2. - Explanations as in Table 2 
Tabela 4. Grzyby wyizolowane z podstawy źdźbła jęczmienia jarego (Tomaszkowo, 2007)

Table 4. Fungi isolated from stem bases of spring barley (Tomaszkowo, 2007)

\begin{tabular}{|c|c|c|c|c|c|c|c|c|c|c|}
\hline \multirow{3}{*}{ Gatunek grzyba - Species of fungi } & \multicolumn{8}{|c|}{ Obiekty - Objects } & \multirow{3}{*}{$\begin{array}{c}\text { Suma } \\
\text { Sum }\end{array}$} & \multirow{3}{*}{$\begin{array}{l}\text { Procent } \\
\text { Percent }\end{array}$} \\
\hline & I & II & III & IV & $\mathrm{V}$ & VI & VII & VIII & & \\
\hline & \multicolumn{8}{|c|}{ liczba kolonii - number of colonies } & & \\
\hline Alternaria alternata (Fries) Keissler & 1 & 1 & - & - & - & 4 & 3 & - & 9 & 6,4 \\
\hline Aureobasidium pullulans (de Bary) Arnaud & 1 & - & - & - & - & - & - & - & 1 & 0,7 \\
\hline Bipolaris sorokiniana (Sacc.) Shoem & - & 2 & - & - & - & - & - & - & 2 & 1,4 \\
\hline Fusarium culmorum (Smith) Sacc. & - & - & 1 & - & 1 & 1 & - & - & 3 & 2,1 \\
\hline F. equiseti (Corda) Sacc. & - & - & - & 1 & - & 1 & - & 1 & 3 & 2,1 \\
\hline F. oxysporum Schlecht em Snyder et Hansen & 8 & - & - & 3 & 1 & 5 & 3 & 5 & 25 & 17,8 \\
\hline F. tricinctum (Beyma) Gams & - & - & - & - & - & - & - & 1 & 1 & 0,7 \\
\hline Fusarium spp. & - & - & - & - & - & 1 & 1 & 1 & 3 & 2,1 \\
\hline Mucor hiemalis Wehmer & 1 & - & 1 & - & - & - & 1 & 2 & 5 & 3,6 \\
\hline Paecilomyces niveus Stolk et Samson & 3 & - & - & - & 1 & - & - & - & 4 & 2,8 \\
\hline Penicillium spp. & 7 & 2 & 9 & 8 & 7 & 6 & 7 & 7 & 53 & 37,8 \\
\hline Phoma medicaginis (Corda) Wollenw. et Hochapf. & - & 1 & - & - & 1 & - & 1 & - & 3 & 2,1 \\
\hline Phoma spp. & - & - & - & 1 & - & - & - & 1 & 2 & 1,4 \\
\hline Rhizopus nigricans Ehrenberg & 2 & 1 & 2 & - & - & 2 & 6 & 4 & 17 & 12,1 \\
\hline Grzybnie niezarodnikujące - Non sporulating fungi & - & - & 3 & 2 & - & 1 & 2 & 1 & 9 & 6,4 \\
\hline Razem - Total & 23 & 7 & 16 & 15 & 11 & 21 & 24 & 23 & 140 & 100 \\
\hline
\end{tabular}

Objaśnienia pod tabelą 2. - Explanations as in Table 2

Tabela 5. Grzyby wyizolowane z korzeni pszenicy ozimej (Tomaszkowo, 2008)

Table 5. Fungi isolated from roots of winter wheat (Tomaszkowo, 2008)

\begin{tabular}{|c|c|c|c|c|c|c|c|c|c|c|}
\hline \multirow{3}{*}{ Gatunek grzyba - Species of fungi } & \multicolumn{8}{|c|}{ Obiekty - Objects } & \multirow{3}{*}{$\begin{array}{l}\text { Suma } \\
\text { Sum }\end{array}$} & \multirow{3}{*}{$\begin{array}{l}\text { Procent } \\
\text { Percent }\end{array}$} \\
\hline & $\mathrm{I}$ & II & III & IV & $\mathrm{V}$ & VI & VII & VIII & & \\
\hline & \multicolumn{8}{|c|}{ liczba kolonii - number of colonies } & & \\
\hline 1 & 2 & 3 & 4 & 5 & 6 & 7 & 8 & 9 & 10 & 11 \\
\hline Acremonium strictum Gams & 1 & 1 & - & - & - & - & - & - & 2 & 1,4 \\
\hline Alternaria alternata (Fries) Keissler & - & - & - & - & - & 2 & - & - & 2 & 1,4 \\
\hline Aspergillus spp. & - & 2 & - & - & - & 1 & 3 & - & 6 & 4,2 \\
\hline Aureobasidium bolleyi (Sprague) von Arx & 1 & - & - & - & 1 & 3 & - & - & 5 & 3,5 \\
\hline A. pullulans (de Bary) Arnaud & 1 & - & 1 & - & 1 & - & - & - & 3 & 2,1 \\
\hline Bipolaris sorokiniana (Sacc.) Shoem & - & - & - & - & 1 & 1 & 1 & - & 3 & 2,1 \\
\hline Botrytis cinerea Persoon ex Fries & - & - & - & - & - & - & - & 2 & 2 & 1,4 \\
\hline Epicoccum nigrum (Link) & - & - & - & - & - & 1 & - & - & 1 & 0,7 \\
\hline Fusarium avenaceum (Fr.) Sacc. & - & - & - & - & - & - & 1 & 1 & 2 & 1,4 \\
\hline F. equiseti (Corda) Sacc. & 1 & 2 & - & - & - & 1 & 1 & - & 5 & 3,5 \\
\hline F. oxysporum Schlecht em Snyder et Hansen & - & - & - & 1 & - & 1 & - & - & 2 & 1,4 \\
\hline F.poae (Beyma) Gams & - & - & - & 1 & 1 & - & - & 1 & 3 & 2,1 \\
\hline F. sporotrichioides (Fries) Cesati & 1 & - & - & - & - & - & - & - & 1 & 0,7 \\
\hline F. tricinctum (Beyma) Gams & 1 & - & - & - & 1 & - & - & 2 & 4 & 2,8 \\
\hline Fusarium spp. & - & - & - & 1 & - & 1 & 1 & - & 3 & 2,1 \\
\hline Gliocladium catenulatum Gilman et Abbott & 2 & - & - & 1 & - & - & - & 1 & 4 & 2,8 \\
\hline Microdochium nivale (Fries) Cesati & - & - & - & - & - & 1 & 1 & - & 2 & 1,4 \\
\hline Mortierella alpina Peyronel & 2 & 5 & 2 & 4 & 3 & 1 & 1 & 1 & 19 & 13,4 \\
\hline M. zonata Linnem. ex Gams & 2 & - & 2 & 1 & 1 & - & - & - & 6 & 4,2 \\
\hline Mortierella spp. & 1 & - & - & - & - & 1 & - & - & 2 & 1,4 \\
\hline
\end{tabular}




\begin{tabular}{l|c|c|c|c|c|c|c|c|c|c}
\hline \multicolumn{1}{c|}{1} & 2 & 3 & 4 & 5 & 6 & 7 & 8 & 9 & 10 & 11 \\
\hline Mucor circinelloides van Tieghem & - & - & 3 & - & - & 1 & - & - & 4 & 2,8 \\
\hline M. fragilis Fres. & - & - & - & - & - & - & - & 1 & 1 & 0,7 \\
\hline Penicillium spp. & 2 & 3 & 3 & 3 & 1 & 2 & 5 & 7 & 26 & 18,4 \\
\hline Phoma medicaginis (Corda) Wollenw. et Hochapf. & - & - & - & - & 2 & - & 1 & 1 & 4 & 2,8 \\
\hline Rhizopus nigricans Ehrenbreg & - & - & - & - & - & - & - & 1 & 1 & 0,7 \\
\hline Rhizoctonia solani Kuhn & - & - & - & 1 & 1 & - & - & - & 2 & 1,4 \\
\hline Trichocladium asperum Harz & - & - & - & - & - & 1 & - & - & 1 & 0,7 \\
\hline Trichoderma aureoviride Rifai & - & 1 & - & - & 1 & - & 2 & - & 4 & 2,8 \\
\hline T. hamatum (Bon.) Bain. & 2 & - & - & - & - & - & - & - & 2 & 1,4 \\
\hline T. harzianum Rifai & - & - & - & 3 & - & - & - & - & 3 & 2,1 \\
\hline T. koningii Oud. & - & 1 & - & 1 & - & - & - & 1 & 3 & 2,1 \\
\hline T. viride Pers. et Gray & 2 & 1 & - & 1 & 1 & - & - & 4 & 9 & 6,4 \\
\hline Zygorrhynchus moelleri Vuill. & - & - & - & - & - & 1 & - & - & 1 & 0,7 \\
\hline Grzybnie niezarodnikujące - Non sporulating fungi & - & 1 & - & - & 1 & 1 & - & - & 3 & 2,1 \\
\hline Razem - Total & 19 & 17 & 11 & 18 & 16 & 20 & 17 & 23 & 141 & 100 \\
\hline
\end{tabular}

Objaśnienia pod tabelą 2. - Explanations as in Table 2

Tabela 6. Grzyby wyizolowane z podstawy źdźbła pszenicy ozimej (Tomaszkowo, 2008)

Table 6. Fungi isolated from stem bases of winter wheat (Tomaszkowo, 2008)

\begin{tabular}{|c|c|c|c|c|c|c|c|c|c|c|}
\hline \multirow{3}{*}{ Gatunek grzyba - Species of fungi } & \multicolumn{8}{|c|}{ Obiekty - Objects } & \multirow{3}{*}{$\begin{array}{l}\text { Suma } \\
\text { Sum }\end{array}$} & \multirow{3}{*}{$\begin{array}{l}\text { Procent } \\
\text { Percent }\end{array}$} \\
\hline & I & II & III & IV & $\mathrm{V}$ & VI & VII & VIII & & \\
\hline & \multicolumn{8}{|c|}{ liczba kolonii - number of colonies } & & \\
\hline Acremonium strictum Gams & - & - & 4 & 1 & - & - & - & - & 5 & 3,5 \\
\hline Alternaria alternata (Fries) Keissler & 3 & 2 & 2 & 3 & - & - & - & 1 & 11 & 7,8 \\
\hline Aspergillus niger van Teighem & - & - & 4 & - & 2 & - & - & - & 6 & 4,2 \\
\hline Aureobasidium pullulans (de Bary) Arnaud & - & - & - & - & - & - & 1 & 2 & 3 & 2,1 \\
\hline Bipolaris sorokiniana (Sacc.) Shoem & 2 & - & - & - & 1 & - & - & 2 & 5 & 3,5 \\
\hline Cladosporium cladosporioides (Fresunius) de Vries & - & - & - & - & - & - & 2 & - & 2 & 1,4 \\
\hline Epicoccum nigrum (Link) & - & - & 2 & - & 1 & - & - & - & 3 & 2,1 \\
\hline Fusarium avenaceum (Fr.) Sacc. & 1 & - & - & - & - & 3 & - & - & 4 & 2,8 \\
\hline F. culmorum (Smith) Sacc. & - & - & - & 3 & - & - & - & - & 3 & 2,1 \\
\hline F. equiseti (Corda) Sacc. & - & 1 & - & - & 3 & 2 & 2 & 3 & 11 & 7,8 \\
\hline F. graminearum Schwabe & - & - & - & - & - & 2 & - & - & 2 & 1,4 \\
\hline F. oxysporum Schlecht em Snyder et Hansen & 4 & 1 & 1 & 4 & - & 3 & 4 & 1 & 18 & 12,7 \\
\hline F. poae (Beyma) Gams & - & - & - & 3 & 3 & 3 & 3 & 4 & 16 & 11,3 \\
\hline F. sporotrichioides (Fries) Cesati & - & - & - & - & - & 3 & - & - & 3 & 2,1 \\
\hline F. tricinctum (Beyma) Gams & - & 1 & - & - & 4 & 3 & - & - & 8 & 5,7 \\
\hline Mortierella spp. & 3 & 1 & - & - & - & - & - & - & 4 & 2,8 \\
\hline Mucor circinelloides van Tieghem & - & 1 & - & - & - & - & - & - & 1 & 0,7 \\
\hline M. fragilis Fres. & 5 & - & - & 1 & - & - & - & - & 6 & 4,2 \\
\hline Penicillium spp. & 2 & 2 & 5 & - & 2 & - & - & - & 11 & 7,8 \\
\hline Phoma spp. & 1 & - & - & - & 1 & - & - & - & 2 & 1,4 \\
\hline Rhizopus nigricans Ehrenbreg & - & - & - & 1 & - & - & - & - & 1 & 0,7 \\
\hline Trichoderma koningii Oud. & - & - & - & - & 1 & - & - & - & 1 & 0,7 \\
\hline Grzybnie niezarodnikujące - Non sporulating fungi & 3 & 2 & 3 & 4 & - & - & 3 & - & 15 & 10,6 \\
\hline Razem - Total & 22 & 11 & 21 & 18 & 18 & 19 & 15 & 18 & 141 & 100 \\
\hline
\end{tabular}

Objaśnienia pod tabelą 2. - Explanations as in Table 2 
źdźbłach, nasionach zbóż oraz na innych roślinach na całym świecie. Są to grzyby, które wytwarzają toksyny szkodliwe dla roślin, zwierząt i ludzi (Grajewski 2005; Pląskowska 2005).

Wśród izolatów z porażonych korzeni oraz podstawy źdźbła znajdowały się zarówno gatunki patogeniczne, jak i saprotroficzne. Większość uzyskanych gatunków uważana jest za powszechnie występujące w środowisku glebowym, będące pierwotnymi kolonizatorami korzeni zbóż (Kurowski 2002).

\section{Wnioski / Conclusions}

1. Najniższe nasilenie chorób obserwowano na obiekcie nienawożonym.
2. Nawożenie gnojowicą wpłynęło niekorzystnie na zdrowotność jęczmienia jarego.

3. Grzyby rodzaju Fusarium stanowiły największe zagrożenie dla uprawianych zbóż.

4. Z porażonych źdźbeł zbóż najczęściej izolowano $F$. oxysporum, F. equiseti i $F$. culmorum.

5. Potencjalne patogeny zbóż najliczniej występowały na obiekcie nawożonym obornikiem oraz nawożonym jedynie nawozami mineralnymi.

6. Grzyby wykazujące działanie antagonistyczne wobec patogenów liczniej izolowano $\mathrm{z}$ roślin $\mathrm{W}$ obiekcie kontrolnym, a także nawożonym gnojowicą w mniejszej dawce $\mathrm{z}$ PK, obornikiem z PK i obiekcie nawożonym jedynie nawozami mineralnymi.

\section{Literatura / References}

Brzozowski J., Brzozowska I., Balkiewicz K. 2000. Wpływ zróżnicowanych zabiegów ochronno-nawozowych na zdrowotność i plonowanie pszenicy ozimej. Fragmenta Agronomica 1 (69): 11-22.

Cwojdziński W., Nowak K. 2000. Wpływ nawożenia na wysokość i jakość plonu roślin w 6 rotacjach statycznego doświadczenia nawozowego. Journal of Research and Applications in Agricultural Engineering 211 (84): 63-68.

Filipek T. 2005. Dynamika antropogenicznych przyczyn zakwaszenia gleb w Polsce w ostatnich 30 latach. Nawozy i Nawożenie Fertilizers and Fertilization 2 (23): 67-83.

Fotyma M., Pietruch C. 2005. Aktualny stan zakwaszenia gleb i zapotrzebowanie na nawozy wapniowe w Polsce. Nawozy i Nawożenie - Fertilizers and Fertilization 3 (8): $27-49$.

Grajewski J. 2005. Mikotoksyny i patogenne pleśnie źródłem zagrożenia dla człowieka i zwierząt. Agro Serwis. Materiały z Forum Producentów Roślin Zbożowych, Kukurydzy i Rzepaku: 8-11.

Gutmański I., Mikita J. 2000. Wpływ obornika i dawek azotu mineralnego na wydajność i jakość przetwórczą korzeni buraka cukrowego oraz na zawartość azotanów w profilu glebowym w okresie wegetacyjnym. Journal of Research and Applications in Agricultural Engineering 218 (84): 121-126.

Hamkalo Z. 2000. Soil potassium availability in agrophytocenosis under conditions of long-studing application of mineral fertility. Naukovy Visnyk Chernivetskogo Universitetu: Zbirnyk Naukovych Prats. Vyp. 80 - Chernivtsi: 35-46.

Hinfner K., Papp F. 1964. Atlas chorób i szkodników zbóż i kukurydzy. PWRiL, Warszawa, 206 ss.

Jaczewska-Kalicka A. 2006. Zmienność nasilenia rozwoju chorób grzybowych pszenicy ozimej w latach 2001-2005. [The effects of fungicides on rate and duration of grain filling in winter wheat in relation to maintenance of flag leaf green area]. Progress in Plant Protection/Postępy w Ochronie Roślin 46 (1): 451-460.

Jaczewska-Kalicka A., Krasiński T. 2010. Grzyby patogeniczne dominujące w uprawie pszenicy ozimej w latach 2006-2009. [Pathogenic fungi dominating in winter wheat in the years 2006-2009]. Progress in Plant Protection/Postępy w Ochronie Roślin 50 (2): $642-647$.

Kaczor A., Kozłowska J. 2003. Wpływ nawożenia roślin różnymi formami azotu i potasu na odczyn i zasobność gleby w fosfor. Zeszyty Problemowe Postępów Nauk Rolniczych 493: 375-379.

Korbas M., Martyniuk S., Rozbicki J., Beale R. 2001. Zgorzel podstawy źdźbła oraz inne choroby podsuszkowe zbóż. Fundacja Rozwój SGGW, Warszawa, 60 ss.

Kurowski T.P. 2002. Studia nad chorobami podsuszkowymi zbóż uprawianych w wieloletnich monokulturach. UWM, Olsztyn. Rozprawy i Monografie 56, 86 ss.

Kurowski T.P., Marks M., Kurowska A., Orzech K. 2005. Stan sanitarny i plonowanie jęczmienia jarego w zależności od sposobu uprawy roli. Acta Agrobotanica 58 (2): 335-346.

Łacicowa B. 1964. Badania mikroflory materiału siewnego pszenicy uprawianej na obszarze województwa lubelskiego, uwzględniające szczególnie grzyby patogeniczne. Annales Universitatis Mariae Curie-Skłodowska Seria E, XIX 18: 381-401.

Mackiewicz D., Drath I. 1972. Wpływ zmianowania na stopień porażenia pszenicy przez łamliwość źdźbeł oraz na jej plonowanie. Biuletyn Informacji Publicznej Instytutu Ochrony Roślin 54: 153-169.

Majchrzak B., Kurowski T.P., Okorski A. 2004. Zdrowotność liści i kłosów pszenicy jarej (Triticum aestivum L.) uprawianej po różnych przedplonach. Acta Agrobotanica 57 (1-2): 119-129.

Martyniuk S. 1986. Ekologia i właściwości fitopatogena korzeni zbóż Gaeumannomyces graminis (Sacc). Arx i Olivier i grzybów pokrewnych z rodzaju Phialophora. IUNG, Puławy, 85 ss.

Mercik S., Stepień W., Lenart S. 2000. Żyzność gleb w trzech systemach nawożenia: mineralnym, organicznym i organicznomineralnym - w doświadczeniach wieloletnich. Cz. I. Właściwości fizyczne i fizykochemiczne gleb. Journal of Research and Applications in Agricultural Engineering 211 (984): 311-316.

Pląskowska E. 2005. Zdrowotność pszenicy jarej uprawianej w siewie czystym i w mieszaninach odmian. Zeszyty Naukowe Akademii Rolniczej we Wrocławiu 528, 142 ss.

Reinecke P., Fehmann H. 1979. "Rhizoctonia cerealis" van der oeven an Getride in der Bundesrepublik Deutschland. Zeitschrift für Pflanzenkrankheiten und Pflanzenschutz 93 (4): 359-367.

Żółtańska E., Woźniak J. 2003. Skuteczność wybranych zapraw nasiennych w ochronie pszenicy jarej przed grzybami z rodzaju Rhizoctonia. [Effectveness of selected fungicides used for seed dresing in the spring wheat protection against fungi of the genus Rhizoctonia]. Progress in Plant Protection/Postępy w Ochronie Roślin 43 (2): 1068-1072. 